\title{
Impact of foreign remittances on school enrolment and educational expenditures in district Peshawar, Pakistan
}

\author{
Sajid Gul*1 ${ }^{*}$ Ali Zeb ${ }^{2}$ | Obaid Ullah ${ }^{3}$ | Guo Mingyan ${ }^{4}$ \\ 1. School of Mathematics \& Statistics, Zhengzhou University, Zhengzhou, Henan, China. \\ 2. School of Business, Zhengzhou University, Zhengzhou, Henan, China. \\ 3. School of Economics, Lanzhou University, Lanzhou, Gansu, China. \\ 4. School of International Studies, Zhengzhou University, Zhengzhou, Henan, China. \\ *Corresponding Author Email: sgqaustat@gmail.com | sajid@gs.zzu.edu.cn
}

\begin{abstract}
This study aims to identify the effects of foreign remittances on school enrolment and the educational expenditures of children in the Peshawar district. Primary data were acquired by simple random sampling and a questionnaire. Correspondingly, the logit approach and Heckman selection theory were utilized to examine school enrolment and educational expenses. The marginal effects were evaluated to determine the co-efficient. The study's findings indicate that Per Capita Remittances (PCRM) have a highly substantial and beneficial effect on children's school attendance, with a $(10.8 \%)$ point increase in school enrolment for every 100 rupees rises in Per Capita Remittances (PCRM). Suppose a household's Per Capita Income (PCIM) improves by one hundred rupees, the probability of children enrolling in school increases by (0.17). The results indicate that PCRM and educational costs per kid are significantly and positively correlated. Educational spending per child increases by 12.01 rupees for every 100 rupees rise in family remittances per capita, whereas every 100 rupees increase in per capita income increases educational expenditure per kid by (8.38 PKR). Which leads to an $8.38 \%$ marginal propensity to spend on child education.
\end{abstract}

\section{Article History}

Received:

June 21, 2021

Revised:

July 21,2021

Re-revised:

September 17, 2021

Accepted:

October 27, 2021

Published:

November 2, 2021

Keywords: Heckman selection model, Logit approach, per-capita income, per-capita remittances, foreign remittances, educational expenditure, school enrolment.

How to Cite: Gul, S., Zeb, A., Ullah, O., \& Mingyan, G. (2021). Impact of foreign remittances on school enrolment and educational expenditures in district Peshawar, Pakistan. Liberal Arts and Social Sciences International Journal (LASSIJ), 5(2), 209-221. https://doi.org/10.47264/idea.lassij/5.2.14

Publisher's Note: IDEA PUBLISHERS (IDEA Publications Group) stands neutral with regard to the jurisdictional claims in the published maps and the institutional affiliations.

Copyright: ( 2021 The Author(s), published by IDEA PUBLISHERS (IDEA Publications Group).

Licensing: This is an Open Access article published under the Creative Commons AttributionNonCommercial 4.0 International License (http://creativecommons.org/licenses/by-nc/4.0/) 


\section{Introduction}

Migration, whether internal or external to the country's geographical boundaries, has consistently and considerably impacted the socio-economic status of remittance recipient households. Researchers in demography, sociology, psychology, and economics, among others, are keen to elucidate the possible causes of this mass migration and the consequences for residents, migrants, and their families (Khan et al., 2008). There are a variety of elements that contribute to the enhancement of a society's level of living. Some of these elements, however, are particularly important in a certain community. Inflows of international remittances to Third-World economies are one such element. Remittances are significant because they significantly contribute to the economic development of households and the wider economy in these impoverished countries. They are not only a major source of foreign money for less developing countries in general and Pakistan in particular, but they are also a source of poverty alleviation.

The significance of remittances stems from the fact that they assist households in an economic recovery and provide a base for earning foreign currency in emerging economies. Overseas remittances also contribute to developing human capital and poverty alleviation in third-world countries (Khan, 2016). The inflow of external has become three-fold in developing economies in the last two decades and this inflow does affect the living standards of the people in host countries. Foreign Direct Investment (FDI) is left behind by overseas remittances and positively affects the foreign reserves of developing countries (World Bank, 2015). Overseas remittances have positive effects if they overpay for the cost of income due to migration and increase the income of helping them out of poverty. Their consumption of goods and services also increases, including health care consumption and education. Foreign remittances also help the recipient households invest in some business, improving their living standard (Huay \& Bani, 2018).

External migration of parents may also badly disturb the educational activities of left-behind children. Due to the migration of father or elder brother, the burden of work-load would fall on left-behind members they would not be able to allot more time to their studies. Similarly, there are chances that in the absence of a father, the children may involve in some anti-social activities, and their educational performance will be impaired (Koska et al., 2013). Cebotari et al. (2016) examined the effects of international migration on children's educational outcomes in Georgia and Moldova. They observed that migrant fathers and caretaker mothers benefit children's academic achievement. Zhu et al. (2014) examines the effects of foreign migration and remittances on school enrollment and investment in education. Naz et al. (2016) also find a positive and significant relationship between migrant's remittances and children school enrollment in Dir, Pakistan. Similarly, another researcher investigates the effect of remittances on child schooling in Pakistan. The Instrumental Variable (IV) Probit model results indicate that children from remittance-recipient households receive a higher level of education than children from non-remittance-recipient families in rural areas.

The main objective of this study is to analyze the impact of foreign remittances on school enrollment and educational expenditures of children in district Peshawar. This study employs Logit techniques and the Heckman selection model for data estimation to quantify slope coefficients and estimate marginal effects of school enrollment and educational expenditures. The rest of the paper is organized in the following order: Section-2 provides a literature review of the study. Section-3 describes the theoretical framework of study. The methods and materials 
are provided in Section-4. Moreover, the study's results and main findings, limitations, and policy implications are discussed in the results and discussion in section-5. Finally, section-6 provided the research conclusions.

\subsection{An overview of remittances in Pakistan}

According to a survey by the Overseas Employment Corporation (OEC), there were more than 3 million overseas migrants from Pakistan in 2015. Around $96 \%$ of this entire labour migrants originated in Gulf Cooperative Nations (GCC) member countries. Saudi Arabia is the primary country liable for them. Arabia received the most migrants, followed by the United Arab Emirates, Kuwait, Oman, Qatar, and Bahrain (https://beoe.gov.pk; https://oec.gov.pk).

The Bureau of Emigration and Overseas Employment (BEOE) reports that the number of emigrants increased from $(142,135)$ to $(946,571)$ between 2005 and 2015, indicating a sustained increase in emigration. Conversely, the number of emigrants fell to $(382,439)$ in 2018. Emigration increased marginally in 2019 , reaching $(625,203)$. On the other hand, In July 2020, remittances from Pakistanis living abroad surpassed (\$2768) billion, the greatest level in Pakistan's history. This statistic represents a (12.2\%) growth over June 2020 and a (36.5\%) increase over July 2019 (https://beoe.gov.pk).

The Figure-1 indicates that remittances have almost doubled during the last decade; foreign remittances show an increasing trend with fewer fluctuations, i.e., increasing from 11.2 billion dollars to 23.13 billion dollars during 2010-11 to 2019-20. Despite the Covid-19 pandemic, the inflow of remittances from Overseas Pakistani witnessed an increase of $24.9 \%$ during the first six months of FY-21 compared to the corresponding period of last year.

Figure 1: Remittances received by Pakistan during last 10 years

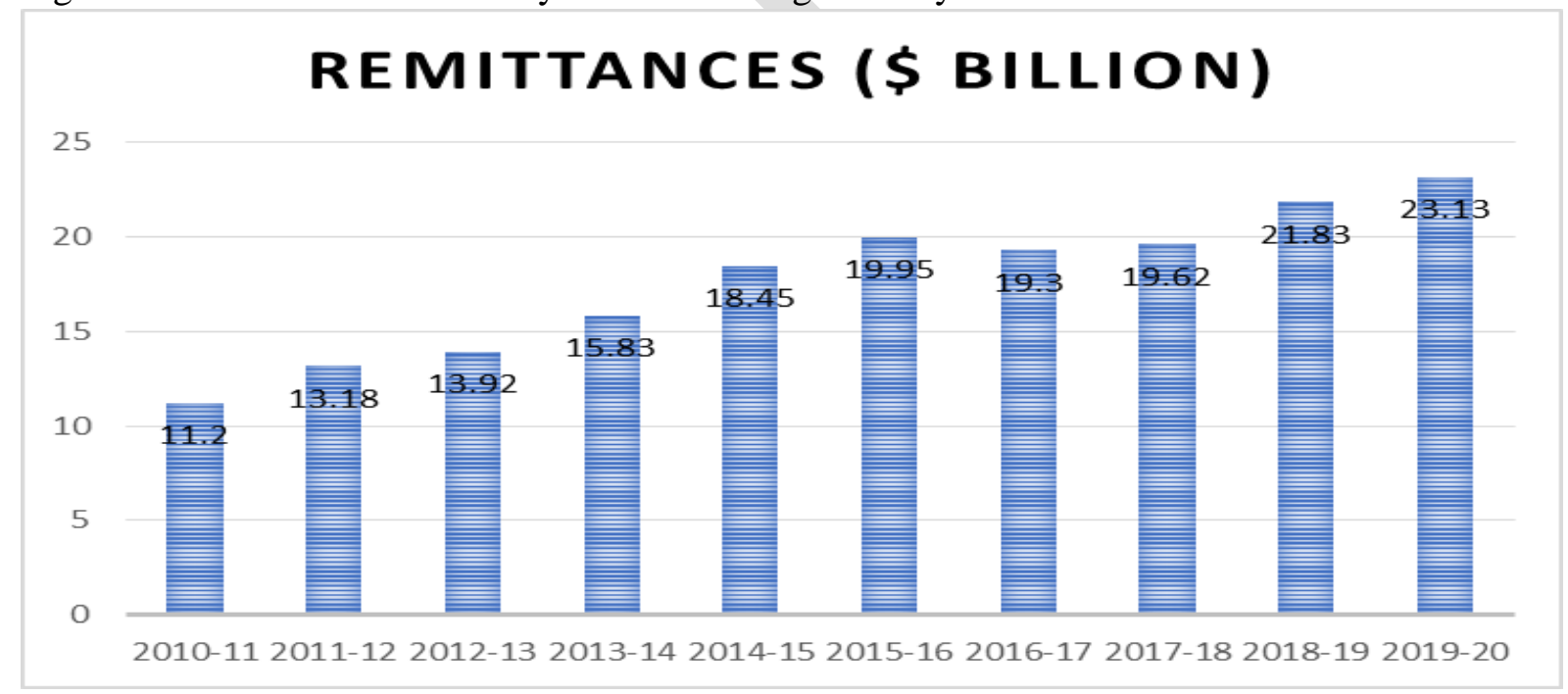

Khyber Pakhtunkhwa is Pakistan's second greatest exporter of the workforce, following Punjab. Between 1971 and 2020, the number of qualified and skilled workers will be significantly lower than unskilled and semi-skilled workers. External remittances account for about $10 \%$ of the average monthly household income in Khyber Pakhtunkhwa, higher than in any other province $(5 \%, 1.5 \%$, and $0.7 \%)$ for Punjab Balochistan and Sindh, accordingly (BEOE, 2020). As per the Bureau of Emigration and Overseas Employment (BEOE) (2015), 
Pakistan is the second-largest source of labour migration in South Asia, after India. Around $80 \%$ of immigrants come from India, while Pakistan contributes up to $19 \%$. Highlighted the history of foreign remittances, the objective of this study is to determine the effect of foreign remittances on school enrollment and to assess whether foreign remittances have a substantial effect on the educational expenditures of children in the Peshawar district. The global COVID19 pandemic has sent many countries' economies spiralling downward. Countries such as Pakistan have been hit especially hard due to developing economies and social safety nets. However, remittances towards Pakistan have shown an increase; a total of \$23.13 Billion remittances were recorded during the FY 2019-20. Saudi Arabia, UAE, USA and UK remained the top source countries in terms of remittances.

Figure 2: District wise human capital emigration among the leading districts of Khyber Pakhtunkhwa across Pakistan.

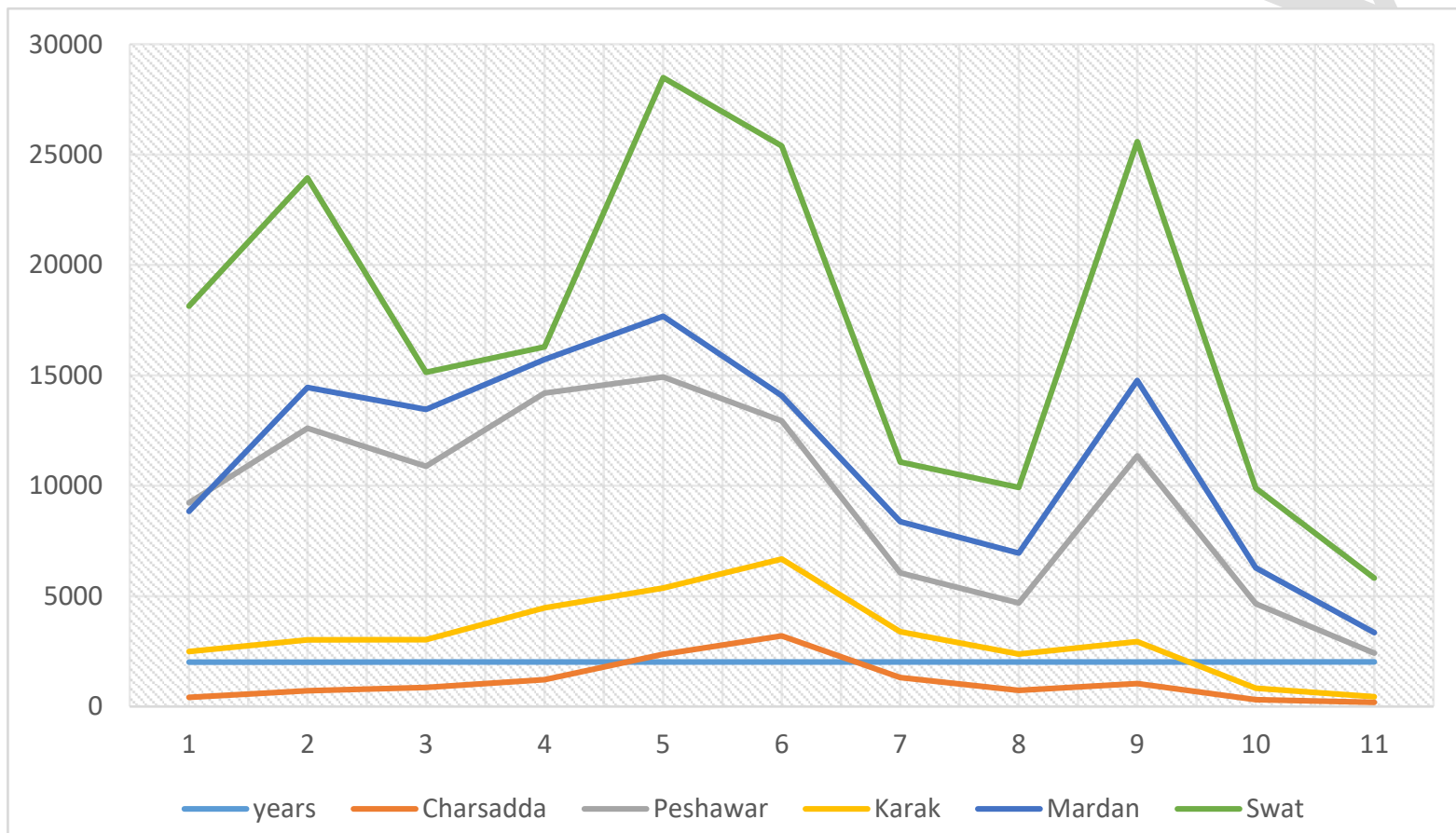

Note: Line graphs show that Swat, Mardan and Peshawar are the leading labour exporter, followed by Karak and Charsadda districts.

\section{Literature review}

\subsection{Positive relationship between remittances and enrollment}

Matano and Ramos (2013) also, examine the effects of overseas remittances on children's education in Moldova. Data is extracted from CBSAXA Moldovan Household Survey. They employ probit and Instrumental Variable (IV) estimation technique. The study results reveal that remittances increase the probability of getting higher education for both boys and girls. Malik (2015) analyze the relationship between received remittances and education. Primary data is collected through a random sample technique. The study results indicate that on micro level, foreign remittances have a highly significant and positive impact on household education. It is also evident from the study results that gender, age, marital status and amount of remittances are also important determinants of school enrolment in recipient households. 
Hines and Simpson (2019) opine the link between the received remittances and household allocation pattern. The key finding of their study shows that increasing remittances enhance educational investment in Kenya. Yousafzai (2015), considers the role of external remittances on Pakistan households' spending behaviour by using Household Income and Expenditure Survey (HIES). He 13 concludes that expenditures on food are high in non-remittance recipient households and less on physical and human capital whereas the beneficiary household invests more in physical and human capital. The outcomes of the study also support the permanent income hypothesis of consumption. Alishani and Nushi (2012) investigate the socio-economic effects of overseas remittances on left-behind families in Kosovo. They confirm that remittances increase household income and their 14 ability to achieve education and health care services.

\subsection{Negative relationship between remittances and enrollment}

Khan (2016) investigates the 24 relationships between external migration and children education in district Gujrat, Pakistan. A survey is conducted to collect primary data for the study. The results of his study confirm that external remittances posit a significant and positive effect on the children's schooling. The study also confirms that remittances positively and significantly affect school enrolment, attendance, and academic performance of male and female children at the primary level. But beyond the primary level, the academic performance and school enrolment of female children in remittance recipient households remain high, and the school enrolment of male children tend to fall when their fathers go abroad.

Démurger and Wang (2016) scrutinize the allocation of foreign remittances in rural areas of China. A Propensity matching score is applied using data from the Migration of Rural-Urban in China (MRUC) survey, and average treatment effects are estimated. The results confirm a strong negative impact of foreign remittances on education expenditure. Fleming (2016) examines the impact of domestic as well as foreign remittances on school enrolment in Nepal. He extracted the data for his study from Nepal Living Standards Survey (NLSS) 2010-11. The estimates of the bivariate probit model show that children of households with internal migration have high school enrollment compared to households with external migration of father or mother.

Chang et al. (2019) investigates the effects of external migration and overseas remittances on school enrolment and educational investment. The China Household Income Project (CHIP 2013) data is used. The study results show the adverse effect of migration and remittances on educational investment and this adverse impact of remittances on school enrolment is high at higher level of education compared to the primary level of children education. Dietz et al. (2015) analyze the effects of foreign migration and overseas remittances on the education of the left-behind in Tajikistan. The data of the Tajikistan Living Standard Survey (TLSS) is used. The results of the 25 baseline fixed effects OLS estimation reveal that the probability of school enrolment tends to fall as remittances from abroad increases. Meng and Yamauchi (2015) examine the impact of the remittance on the health and education of left-behind children. For this study, data is extracted from Rural-Urban Migration in China (RUMiC). The outcome of the study shows that parental migration hurts the schooling of children. The Mexican Family Life Survey (MFLS) and Indonesian Family Life Survey (IFLS) data are taken. The study's outcomes show that children of migrant parents are worse off compared to children who live with their parents. 


\section{Theoretical framework}

The analysis of the impact of foreign remittances on school enrolment will lead one that external remittances and school enrolment are linked positively and negatively. Intuitively, remittances constitute a part of the income of the households. Then, an increase in the income level of households increases the expenditure on education, keeping the effect of all other important factors of education constant. McKenzie and Rapoport (2006) model has been used to explain the above channels. McKenzie and Rapoport have discussed three channels.

\subsection{Remittances effect}

This effect explains that remittances help to reduce the burden of poverty. An increase in the inflow of remittances would increase the income of households, improve the people living standards, and relax their financial constraints. As a result, an increase in remittances inflow leads to investment in human capital.

\subsection{Disruptive family effect}

The second channel explains that there are negative effects of emigration on children educationalactivities. The negative impact may be that children become involved in antisocial activities due to the absence of a father. Thus, the children academic performance will become worse.

\subsection{Immediate substitution}

The third channel also shows that the current migration of parents affects school enrolment negatively. It is because due to parental migration, there are more chances that children themselves become migrants in the future. As a result, the opportunity cost of children enrollment becomes high due to this immediate substitution effect (Khan, 2016).

Figure 3: Overseas migration and education in migrant's households
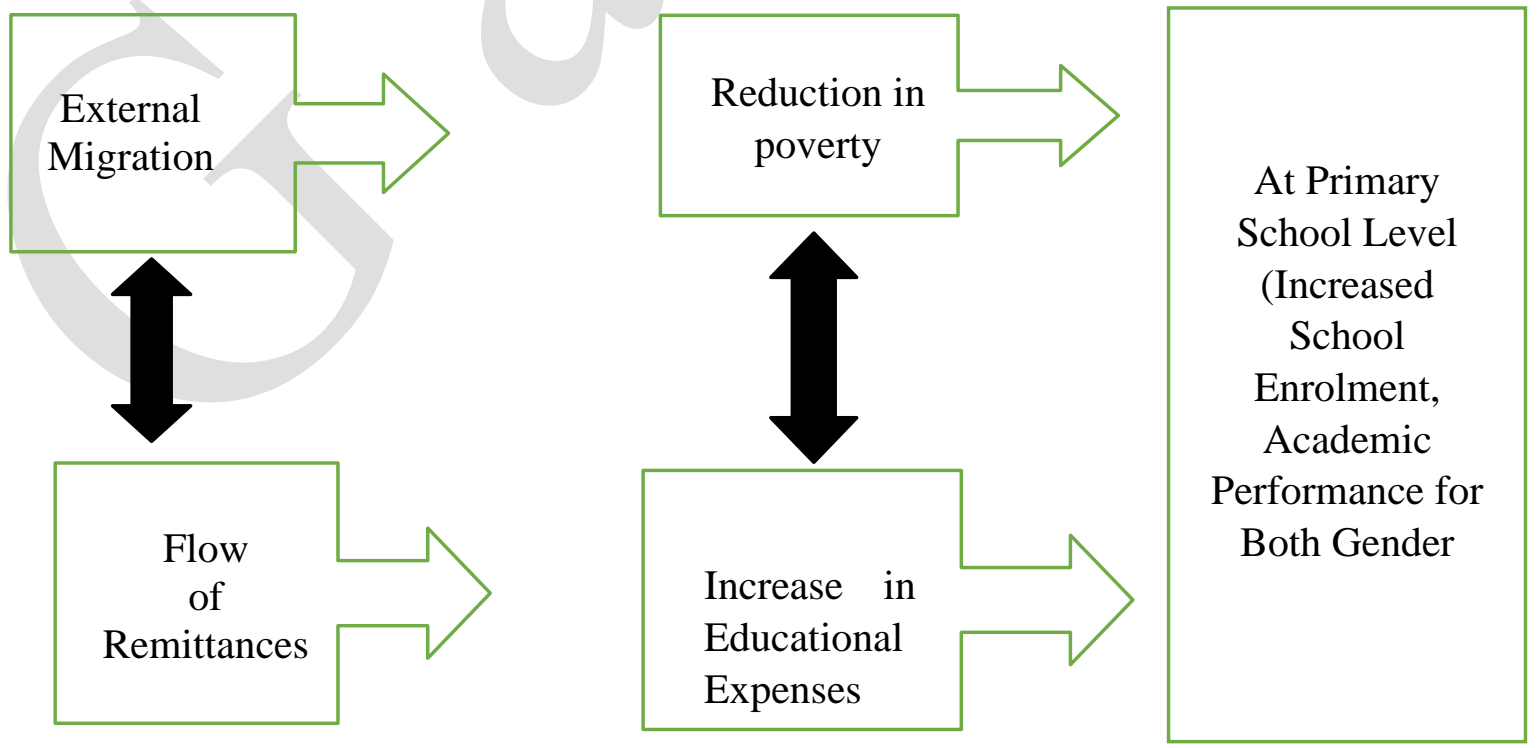
The channel in figure 3 reveals that a poor section of society becomes better off due to external migration, leading to an increase in school enrolment, attendance, and academic performance of the children. An increase in foreign migration increases the income level of people through the flow of remittances. Due to remittances flow, people spend more and more on children education and finally, it leads to increase in the schooling of the children.

\section{Data nature and methodology}

This research used original data collected in Peshawar, Khyber Pakhtunkhwa, Pakistan, via a simple random sampling district. The sample size was 350 in total. The logit approach is used since our dependent variable is binary. Furthermore, the marginal effects are assessed to quantify the magnitudes of variable coefficients, and all the statistical analysis and modelling estimates are obtained by using Statistical software STATA and MS Excel. The second model estimates the Heckman selection model to account for educational spending on children in remittance-receiving households. Due to the binary nature of the dependent variable, i.e., school enrollment (SERi). Numerous researchers have also used this technique in their research, including (Bouoiyour \& Miftah, 2016). The Heckman selection model is used to capture the impact of foreign remittances on educational expenditures. These models are addressed in greater detail below.

\subsection{Logistic model}

$$
\begin{array}{r}
\text { SERi }=\alpha_{0}+\alpha_{1} \text { PCIM }+\alpha_{2} \text { PCRM }+\alpha_{3} \text { AG }+\alpha_{4} \text { GN }+\alpha_{5} \text { ED. } F+\alpha_{6} \text { ED. } M+\alpha_{7} \text { H.S } \\
+\alpha_{8} \text { Reg. } 1+\alpha_{9} \text { Reg. } 2+\alpha_{10} \text { Reg. } 3+\alpha_{11} \text { Reg. } 4+\alpha_{12} \text { Reg. } 5+\mathrm{U}_{\mathrm{i}}
\end{array}
$$

Where $\alpha_{0}$ represents the intercept of the regression model

$\alpha_{i(i=1,2,3, \ldots n)}$ represents the slope of the regression model

$U_{i}$ known as the error term

\subsection{Heckman selection model}

$$
\begin{array}{r}
\mathrm{EEi}=\beta_{0}+\beta_{1} \text { PCIM }+\beta_{2} \text { PCRM }+\beta_{3} \text { AGi }+\beta_{4} \text { GN }+\beta_{5} \text { ED. F }+\beta_{6} \text { ED. M }+\beta_{7} \text { H. S } \\
+\beta_{8} \text { Reg. } 1+\beta_{9} \text { Reg. } 2+\beta_{105} \text { Reg. } 3+\beta_{11} \text { Reg. } 4+\beta_{12} \text { Reg. } 5+U_{i}
\end{array}
$$

Where $\beta_{0}$ represents the intercept of the regression model

$\beta_{i(i=1,2,3, \ldots n)}$ represents the slope of the regression model

$U_{i}$ known as the error term

"EEi" denotes the educational expenditures incurred by "ith" child. "PCRMi" denotes per $\mathrm{n}$ capita remittances received by "ith" households. "AGi" indicates the children's age. The term "PCIMi" refers to the monthly income of the "ith" households. "ED. F." It denotes the father's educational attainment. "ED.M" denotes the mother's educational level. The abbreviation "HS" refers to the size of the household. "Ui" is a stochastic or deterministic word that encompasses all variables affecting a child's school enrollment ("SERi") and educational expenditures ("EEi"). Along with the explanatory variables described previously, the model includes dummy variables for the household head's gender, family type, and dummies for chosen areas, namely "Reg.1", "Reg.2", "Reg.3", "Reg.4", and "Reg.5". 


\section{Results and discussions}

The remittances help to reduce the burden of poverty. However, an increase in inflow of remittances would increase the income of households, improve the people living standards, and relax their financial constraints. As a result, an increase in remittances inflow led to investment in human capital (Bouoiyour \& Miftah, 2016). All estimated coefficients have the anticipated sign. This implies that correlations between a child's school enrollment and other variables are compatible with a priori theory and extant research. As parameter estimates for regression equations demonstrate the impacts of numerous variables on the log of odd of enrolment, they are difficult to analyze and comprehend. Marginal impacts are assessed to avoid this challenge. Due to non-linearity, probability derivatives are not constants but rather functions of all variables on the right-hand side of the equation, and so are variables.

Again, as is customary, these marginal effects are evaluated using the sample mean of the data. The preceding examination of the enrollment equation results is limited to the direction of the relationship between the likelihood of enrolment and its many probable factors, summarized in the table-2. The results indicate that per capita income has a highly substantial and small marginal influence. The logistic regression results indicate that increasing the household's PCIM by one hundred rupees increases the chance of children enrolling in school by 0.17 points. Additionally, PCRM have a significantly substantial effect on children's school enrolment, increasing by 0.108 points for every 100 rupees increase in PCRM.

Table-1: Estimates of the logistic model and their marginal effects

\begin{tabular}{lll}
\hline Explainatory Variables & Logistic Estimates & Marginal effects \\
\hline Intercept & $0.6429(1.43)$ & \\
PCIM & $0.247 * * *(4.22)$ & $0.1720^{* * *}(4.34)$ \\
PCRM & $0.1836^{* * *}(4.92)$ & $0.1080^{* * *}(5.08)$ \\
AG & $0.0809 * * *(3.86)$ & $0.01188^{* * *}(3.94)$ \\
GN & $-0.3440^{* *}(-2.20)$ & $-0.05049 * *(-2.21)$ \\
ED. F & $0.0938^{* * *}(5.50)$ & $0.01378^{* * *}(5.75)$ \\
ED. M & $0.02039 * * *(3.66)$ & $0.0029 * * *(3.86)$ \\
HS & $-0.07677 * * *(-4.39)$ & $-0.01126 * * *(-4.52)$ \\
Reg2 (Uni-Town) & $1.2868^{* * *}(4.00)$ & $0.1888^{* * *}(-4.07)$ \\
Reg3 (Saddar) & $2.2477 * * *(7.48)$ & $0.3299 * * *(8.14)$ \\
Reg4 (Gul bela) & $0.18667(0.52)$ & $0.02741(0.53)$ \\
Reg5 (Essa khel) & $0.9979 * * *(3.05)$ & $0.1464 * * *(3.08)$ \\
Pseudo R ${ }^{2}$ & 24.4 & \\
Likelihood Ratio (Chi-Square) & $334.48 * * *$ & \\
Prob>Chi ${ }^{2}$ & 0.0000 & \\
\hline
\end{tabular}

Note: $(* * *),(* *)$ and $(*)$ reveals level of significance at 1,5 and 10 percent respectively

A reasonable interpretation of the positive link between PCIM and child school enrollment is that households with a high-income level prioritize child school enrollment. On the other side, if household income is low, child labour takes precedence over child education. As expected, 
the influence of the child's age on enrolment is favourable. The enrolment rate increases by 1.18 percentage points for every one-year rise in a child's age. Our findings are consistent with those of Cunningham and Carrol (2011). Our next variable, the Gender of the Kid (GN), is similarly a dummy variable, and the findings indicate a large gender bias in favour of male offspring regardless of income and remittances. Male children enrol at a rate of 5 percentage points greater than female children, even when the impacts of per capita income and remittances are held constant.

Additionally, the data indicate that parental education, namely father education (ED. F) and mother education (ED.M), both have a highly significant and favourable effect on children's school enrolment, although father education (ED. F) is more successful. When the father's education level increases by one year, the enrollment of children increases by 1.37 percentage points. Additionally, the findings indicate that the influence of mother's education (ED.M) on children's school enrollment is slightly less than the father's education. Children's school enrollment improves by 0.29 percentage points with a one-year increase in mother's education (ED.M); these findings corroborate (Salas, 2014).

The Household Size (HS) and the enrollment of children in school are inversely associated. The explanation for this could be that when the size of a poor household increases, it feels more burdened than a wealthy household. The findings of the study indicate that for every additional member in the home, the enrolment rate of youngsters decreases by approximately 1.12 per cent. Finally, we explore the difference in child school enrollment across the district of Peshawar's selected regions.

Region-1 is used as the starting point. Region-3 has the greatest enrolment rate of youngsters, followed by region-2. In region-3, the enrollment ratio is 67.10 percentage points lower than in the base category region. School enrollment in region-2 is 82.12 percentage points lower than in region-1. Children in region-5 attend school at a rate that is 86.4 percentage points lower than in region-1. Similarly, region-4 has the lowest rate of school enrolment. The low enrolment rate in regions 5 and 4 of district Peshawar is due to poor economic conditions of parents, an insufficient number of schools, inadequate transportation facilities, and a lack of public awareness. Pseudo R-squared is 24.4 , which is a fairly respectable value for crosssection data. Prob $>$ Chi2 indicates that the overall model is significant.

In comparison, the Heckman selection model's outcomes are summarized in table-3. The results of our second model, which relate expenditure on child education to its different probable drivers, are vulnerable to sample selection, as child education data are restricted to children enrolled in school. To avoid sample selection bias, Heckman's technique is used. The estimated probit equation 2's conditional likelihood of kid enrolment (Inverse Mills ratio) is employed as an additional regressor in the expense equation. As shown in table-2, regression coefficients are consistent with theory and practically all are statistically significant. The following table summarizes the results of children's educational expenditures. The findings indicate that PCIM positively and significantly affects children's school expenditure. If per PCIM grows by 100 rupees, expenditure on child education increases by 8.38 rupees. This implies that the marginal propensity to spend on child education is 8.38 per cent, a substantial figure. The correlation between PCRM and educational expenditure per child is substantial and favourable. When family remittances per capita increase by 100 rupees, educational expenditure per child increases by 12.01 rupees. 
Table-3: Results of child educational expenditure equation

\begin{tabular}{ll}
\hline Explainatory Variables & Estimated regression coefficients \\
\hline Intercept & $-693.2439(-0.83)$ \\
PCIM & $0.0838^{* * *}(8.29)$ \\
PCRM & $0.1201^{* * *}(3.04)$ \\
AG & $153.55^{* * *}(4.99)$ \\
GN & $-192.73^{* *}(3.0)$ \\
ED. F & $55.6630^{* *}(2.34)$ \\
ED.M & $110.5496^{* * *}(4.02)$ \\
HS & $37.1545(1.30)$ \\
Sch-Dis & $242.7761 * * *(6.36)$ \\
Reg2 (Uni-Town) & $62.5638(0.20)$ \\
Reg3 (Saddar) & $197.0799(0.56)$ \\
Reg4 (Gul bela) & $92.3589(0.28)$ \\
Reg5 (Essa khel) & $222.5619(0.61)$ \\
Pseudo R & 24.4
\end{tabular}

Note: $(* * *),(* *)$ and $(*)$ shows level of significance at 1,5 and 10 percent respectively. Figures in parentheses represent z-statistic.

Additionally, educational spending and a Child's Age (AG) are highly important and are favourably associated. The reason for this positive correlation could be that as the children advance through the grades, their educational expenses such as tuition, stationery, uniforms, and personal expenses grow. Additionally, the results indicate that the gender dummy variable has a statistically substantial coefficient. This indicates that the average expenditure on the female children is 193 Pakistani rupees less than the average expenditure on the male children. Therefore, it indicats a considerable gender bias in terms of the education expenditure and school enrollment.

Parental education is another variable that covers both father education (ED. F) and mother education (ED. M). The findings indicate that when parents are more educated, they invest more in their children's education. Mother education (ED. M) has a more significant and beneficial effect on spending on children's education than the father's education level (ED. F). Household size (HS) has a positive but insignificant link with school expenditure on children. Increases in household size (HS) result in a rise in the number of school-aged children and, consequently, in school expenditures. Finally, we explain the variations in children's school expenditure across four districts in Peshawar. For example, region-5 has the largest educational expenditures on children, at 122.53 rupees per child, compared to region-1.

Similarly, the educational expenditure per child in the region-3 is 97.07 Pakistani rupees greater than that spent in the region-1. The households in the region- 2 spend the least on education, around 38 rupees less than households in the base category region. Educational expenditure per child in region- 4 is marginally lower than in region-1, at about 8 rupees less. The entire model appears to be significant, and the $\mathrm{R}^{2}$ value is 24.4 , which is rather strong for crosssection data. 
Table-2: Descriptive statistic

\begin{tabular}{lcccc}
\hline Variables & Mean & Std. Deviation & Minimum & Maximum \\
\hline School enrolment & 0.716354 & 0.450959 & 0 & 1 \\
Father education & 10.72913 & 4.796797 & 0 & 18 \\
Mother education & 8.568143 & 4.247465 & 0 & 18 \\
Age of children & 11.19421 & 3.645843 & 5 & 19 \\
Sch-Dis & 2.6192 & 3.0939 & 1 & 15 \\
Household Size & 10.454 & 4.503576 & 3 & 24 \\
Remittances & 6936.707 & 16966.6 & 0 & 242857. \\
Per capita income & 7866.643 & 10305.14 & 0 & 110000 \\
\hline
\end{tabular}

\subsection{Future policy recommendations}

This study endorses that overseas remittances play a prime role in improving school enrollment and educational expenditures. Following endorsements may help advance overseas remittances on the venture of children education and household welfare. However, the government should unveil some counselling services for the left-behind members of remittance recipient households, encouraging them to spend more on their children's education. Similarly, technical training programmes need to be provided through professional and vocational training institutions to augment the skills and abilities of potential immigrants. The concerned institutions should disseminate the information about the availability of jobs and the country where better opportunities are available. Finally, the central government should make its best effort to reduce the cost of immigration by subsidizing immigrants. The immigrants may be allowed to pay a part of the cost after going abroad for earning.

\subsection{Limitations of the study}

Apart from factors discussed responsible for school enrollment and educational expenditures, there may be some other factors such as free education, child labour, Illiterate community, poverty eradication programs, school accessibility subject to population, adequate space in classroom subject to several students. The detailed discussions on the impact of these factors are not considered and could be scope for future research.

\section{Conclusions}

This research was intended to assess the impact of the foreign remittances, while focusing on the school enrollment and educational expenditure of children in district Peshawar, Khyber Pakhtunkhwa, Pakistan. The logistic model and Heckman selection model were used to determine the nature of the relationship among the variables. Results of the study showed that foreign remittances have a significant and positive impact on school enrollment and educational expenditure of children in district Peshawar; for every 100 PKR increase in Per Capita Remittances (PCRM), children school enrollment increases by 0.108 points. In general, this study confirmed that foreign remittances positively and significantly affect school enrollment and educational expenditures of children in district Peshawar. Future research on this area can be carried out by comparing the impact of foreign remittances on school 
enrollment in rural and urban areas of the country. Similarly, the impact of foreign remittances on household welfare and study regarding the impact of foreign remittances and economic growth may also be made in future.

\section{Declaration of conflict of interest}

The author(s) declared no potential conflicts of interest(s) with respect to the research, authorship, and/or publication of this article.

\section{Funding}

The author(s) received no financial support for the research, authorship and/or publication of this article.

\section{References}

Alishani, A., \& Nushi A. (2012). Migration and development: the effects of remittances on education and health of family members left behind for the case of Kosovo. Analytical Journal, 5(1), 42-57. https://www.ceeol.com/search/article-detail?id=110862

Bouoiyour, J., \& Miftah, A. (2016). Education, male gender preference and migrants' remittances: Interactions in rural Morocco. Economic Modelling, 57, 324-331. https://doi.org/10.1016/j.econmod.2015.10.026

Cunningham, A., \& Carroll, J. (2011). Age and schooling effects on early literacy and phoneme awareness. Journal of Experimental Child Psychology, 109(2), 248-255. https://doi.org/10.1016/j.jecp.2010.12.005

Cebotari, V., Siegel, M., \& Mazzucato, V. (2016). Migration and the education of children who stay behind in Moldova and Georgia. International Journal of Educational Development, 51, 96-107. https://doi.org/10.1016/j.ijedudev.2016.09.002

Chang, F., Jiang, Y., Loyalka, P., Chu, J., Shi, Y., Osborn, A., \& Rozelle, S. (2019). Parental migration, educational achievement, and mental health of junior high school students in rural China. China Economic Review, 54, 337-349. https://doi.org/10.1016/j.chieco.2019.01.007

Démurger, S., \& Wang, X. (2016). Remittances and expenditure patterns of the left behinds in rural China. China Economic Review, 37, 177-190. https://doi.org/10.1016/j.chieco.2015.12.002

Dietz, B., Gatskova, K., \& Ivlevs, A. (2015). Emigration, remittances and the education of children staying behind: Evidence from Tajikistan. IZA Discussion Paper No. 9515. https://papers.ssrn.com/sol3/papers.cfm?abstract id=2696353

Fleming, N. (2016). Remittances: How international and domestic migration and remittances affect childhood school enrollment in Nepal. California State University. https://www.proquest.com/openview/0539031e74af2bb1aeb7bf0104bdf017/1?pqorigsite $=$ gscholar $\& \mathrm{cbl}=18750$

Hines, A. L., \& Simpson, N. B. (2019). Migration, remittances and human capital investment in Kenya. Economic Notes: Review of Banking, Finance and Monetary Economics, 48(3), e12142. https://doi.org/10.1111/ecno.12142

Huay, C. S., \& Bani, Y. (2018). Remittances, poverty and human capital: evidence from 
developing countries. International Journal of Social Economics, 45(2), 1227-1235. https://doi.org/10.1108/IJSE-10-2017-0454

Khan M., Rahim T., Shah, M. K., Alam A., Naeem M., \& Zeb J. (2008). An assessment of the volume of workers remittances and their socio-economic impact in recipient regions of north-west frontier province, pakistan (a case study of dir district). Sarhad Journal of Agriculture (Pakistan), 24(3), 513-520. http://www.aup.edu.pk/sj_pdf/AN\%20ASSESSMENT\%20OF\%20THE\%20VOLU ME\%20OF\%20WORKERS\%20REMITTANCES.pdf

Khan, S. (2016). The Impact of International Migration on Children ${ }^{e e}$ s Education in Rural Gujrat, Pakistan. International Journal of Social Science and Humanity, 6(3), 226229. https://doi.org/ 10.7763/IJSSH.2016.V6.647

Koska, O. A., Saygin, P. Ö., Çağatay, S., \& Artal-Tur, A. (2013). International migration, remittances, and the human capital formation of Egyptian children. International Review of Economics and Finance, 28, 38-50. https://doi.org/10.1016/j.iref.2013.05.006

McKenzie, D., \& Rapoport, H. (2007). Network effects and the dynamics of migration and inequality: Theory and evidence from Mexico. Journal of Development Economics, 84(1), 1-24. https://doi.org/10.1016/j.jdeveco.2006.11.003

Malik K. 2015. Examining the relationship between received remittances and education in Malawi. https://scholarship.claremont.edu/cmc theses/1096/

Matano, A., \& Ramos, R. (2013). Remittances and educational outcomes: evidence for Moldova. AQR Research Group-IREA, Universitat de Barcelona. http://www ub edu/searchproject/wp-content/uploads/2013/05/SEARCH-WP-310 pdf

Meng, X., \& Yamauchi, C. (2015). Children of migrants: The impact of parental migration on their children's education and health outcomes. IZA Discussion Paper No.9165. https://papers.ssrn.com/sol3/papers.cfm?abstract id=2655114

Naz, A., Ullah, S., Khan, N., Raza, J., \& Ullah, S. (2016). A Relational Analysis of Migration and Remittances Sent By Migrants and Its Impact on the Educational Outcome of Left behind Children in Khyber Pakhtunkhwa Pakistan. Journal of Management Info, 3(2), 1-6. https://readersinsight.net/index.php/jmi/article/view/53

Salas, V. B. (2014). International remittances and human capital formation. World development, 59, 224-237. https://doi.org/10.1016/j.worlddev.2014.01.035

Yousafzai, T. K. (2015). The economic impact of international remittances on household consumption and investment in Pakistan. The Journal of Developing Areas, 49(6), 157-172. https://muse.jhu.edu/article/586750/summary

Zhu, Y., Wu, Z., Peng, L., \& Sheng, L. (2014). Where did all the remittances go? Understanding the impact of remittances on consumption patterns in rural China. Applied Economics, 46(12),

1312-1322. https://doi.org/10.1080/00036846.2013.872764 
Impact of foreign remittances on school enrolment and educational expenditures in district Peshawar ...

Appendic: 